\title{
Towards Qualified Human Resources in the Hospitality Industry: A Review of the Hospitality Management Competencies
}

\author{
Rahman TEMIZKAN ${ }^{1}$ \\ Orhan YABANCl ${ }^{2}$
}

https://orcid.org/0000-0002-9750-1543
https://orcid.org/0000-0001-5079-5030

\begin{abstract}
The increasing internationalization and demands of the global market have put pressure on organizations to equip their staff with critical competencies. Therefore, the purpose of the study is to identify the core competencies regarded as essential in entering the senior management positions of the hotel industry. By employing a mixed method of both quantitative and qualitative techniques, the study was carried out in Turkey. The findings suggest that the core competencies pertain to the leadership, interpersonal, administrative, and conceptual/creative domains of the competency domain model.
\end{abstract}

Keywords: core competencies; hotel industry; hospitality management competencies; human resource development, the competency domain model

\section{Introduction}

Today, it is generally agreed that competencies are the critical elements for a company's long-term success as the increasing internationalization and demands of the global market have required organizations to equip their staff with the key competencies to enable them to work within diverse environments (Nolan, Conway, Farrell \& Monks, 2010). Internationalization, as a conspicuous phenomenon of the twentieth and twenty-first centuries, compels tourism and hospitality firms to compete, attract more tourists and boost their profits (Isik, Dogru \& Sirakaya-Turk, 2018; Dogru, Isik \& Sirakaya-Turk, 2019). Hence, it drives people to adapt to changing and evolving demands in an extremely competitive environment. Digitalization, apart from internationalization, is the ultimate phenomenon that has already started to influence and shape a plethora of businesses, including tourism, in their manifold aspects. Competencies of employees and human resources activities and routines overall are just some of the aspects that digitalization is revolutionizing. As digitalization is changing and streamlining businesses and their human resources processes (Thite, 2019; Baum, 2015), it is transforming the employment requirements and requiring human resources to be equipped with ultimate competencies.

Since tourism is one of the well-known service industries that people work in favor of people (Baum, 2006) and since tourists are much more quality demanding (Baum \& Kokkranikal, 2005) than ever before, competencies of employees have become critically important for tourism employers over the past few decades. As the quality of services depends on the way they are offered by employees (Belias, Vasiliadis \& Velissariou, 2020), both short- and long-term success of tourism and hospitality firms, now, mostly thrive on competent employees. Furthermore, today points to much more competitive tourism business and a much more demanding tourist profile that makes competency-based recruitment a matter of utmost concern. 
The discussion on hospitality management competencies first appeared in the early 1970s (see Morris, 1973). Still much to be done, many studies have been carried out examining the facts and figures of the concept till the day. From the seminal studies of Mariampolski, Spears \& Vaden (1980), Buergermeister (1983), and particularly Tas (1988) onwards, researchers, such as Baum (1990), Christou (2002), Whitelaw (2005), Nolan et al. (2010) brought the subject to discussion. These studies, carried out at different times and locations with different samples, investigated the topic with its numerous aspects. For example, Morris (1973) examined job competencies expected of hotel and restaurant administration graduates for entry-level management positions by applying to the paid membership of the Oklahoma Restaurant Association.

Similarly, Mariampolski, Spears \& Vaden (1980) probed into competencies for entry-level restaurant managers by referring to experienced professionals in restaurant management in the USA. Buergermeister (1983) assessed the educational skills and competencies needed by entry-level hospitality managers in the USA. Probably, the most influencing study on the subject belonged to Tas (1988). In his seminal study, he delved into the most important competencies for hotel general-manager trainees in the USA with a survey of thirty-six items questionnaire. Baum (1990), readdressing the study of Tas (1988), determined the competency needs of hotel industry in the UK by comparing the participants' ratings of competency statements of the two studies, while Christou (2002) discovered the competencies for Greek hotel industry by comparing the mean rates of competencies with those of Tas (1988) and Baum (1990) with the help of the same questionnaire.

In contrast with the countries in which the studies above were carried out, competencies for hotel management positions in countries such as Turkey have not been well studied until the day. Moreover, there is an urgent need to identify the most recent competencies sought to enter the management positions in the industry. Therefore, the main purpose of the study is to identify the most recent key competencies for the management candidates of the hotel industry by referring to some previous studies written in the last decade along with the recent job ads for hotel management candidates and make some recommendations for future research thereupon. The sub-purposes to focus on are as follows: (a) Identify the core competencies for executive positions in the Turkish hotel industry, (b) Compare the perceptions of professionals and academics of the core competencies and evaluate the results of the study in terms of previous studies.

\section{Literature Review}

Most customers expect the best services (Dieke, 2001). With the growing impetus of technology, customers have become more demanding, and thus the competition has become more challenging (Oakland, 2014) in an environment of economic uncertainties (Isik, Sirakaya-Turk \& Ongan, 2019). Kotler, Bowen \& Makens (2010) propound that understanding market settings and customer demands should be the starting point to develop lucrative customer links. Furthermore, the new management model suggests that the focus is on how well we are responding to customers' needs, but not how much we are making (George \& Weimerskirch, 1994). The only way to meet customers' needs seems to be thinking quality-centric (Evans \& Dean, 2003; Swarbrooke \& Horner, 2007). If understood appropriately and devoted to hard work, quality is measurable, and along with that substantially profitable (Crosby, 1980; George \&Weimerskirch, 1994). As quality improves, costs decrease, and thus it results in improved market share, profit, and growth (Ross \& Perry, 1999).

It is well known that the concept of quality is of manufacturing industry origin. It gained wide prominence in time, and the concept was borrowed by various industries, particularly the services (Williams \& Buswell, 2003). Since then, quality in services has been a matter for concern as prevalent as that in manufacturing. Today, it is generally agreed that success and customer loyalty in services are attained through the quality of services that leads to customer satisfaction rather than the price (Kandampully \& Suhartanto, 2000; Christou, 2002).

When the quality of services is under consideration, there are three parties involved in the process: (1) the service provider, (2) the service receiver as an individual, (3) and the service receiver as a company (Rosander, 1985). Here, the emphasis should be given to the receiver of service rather than the provider concerning the nature of the concept. Namely, quality achievement in services depends on good MOT (Normann, 1977) experiences and satisfaction of both internal (employees) and external customers of a firm (Kotler et al., 2010; George \& Weimerskirch, 1994; Bouranta, Chitiris \& Paravantis, 2008). Well satisfied customers stay "loyal" (Kandampully \& Suhartanto, 2000) and share their 
contentment with people at every turn (Kotler et al., 2010). In other words, customer satisfaction results in the reduction of customer relations fade (Touminen \& Kettunen, 2003) to the least possible level. It thus forms a natural market phenomenon by word of mouth (Helm, 2003) that Kotler et al. (2010) define it overall as service-profit-chain.

\subsection{Competent Human Resources as a Factor of Service Quality}

Human resources have become a vital source for attaining organizational performance (Devanna, Fombrun \& Tichy, 1981) and quality, particularly in the post-industrial community. In the last two decades, human resources also have taken center stage in tourism development and management in many countries due to the changing trends in tourism and the competitive environment (Dieke, 2001). Today, tourists are much aware of the quality, and the provision of quality services is becoming ever more essential for the industry to survive in an increasingly competitive international market (Baum \& Kokkranikal, 2005; Isik, Sirakaya-Turk \& Ongan, 2019). Kotler et al. (2010) propound that people are one of the three main ways that service companies of the day can differentiate their service delivery. Here the word 'people' corresponds to more able and reliable customer contact staff of an organization that its competitors do not have (Kotler et al., 2010). Correspondingly, a service quality guru Gronroos (1988) defines a set of criteria for good perceived quality in services consisting of professionalism and skills, attitudes and behavior, accessibility and flexibility, reliability and trustworthiness, recovery, reputation, and credibility, all of which are of people related, unequivocally.

If organizational service quality (Christou, 2002; Jolliffe \& Farnsworth, 2003) and success are gained through people, then the skills (Pfeffer, 1994) and competencies (Tas, 1988; Baum, 1990) of those people are of critical importance. Todays' firms are in a demanding competition for obtaining and retaining the most competent people due to common skills shortage (D’Annunzio-Green, Maxwell \& Watson, 2005; Ayres, 2006). Having industry-specific skills is no longer enough for securing a satisfying job; quite the contrary, competence in problem-solving, communicating with others, allocating resources conveniently, understanding complex interrelationships of the work environment, and so forth is the prevailing trend for employability (Fournier \& Ineson, 2010). In that regard, tourism professionals need to have knowledge, skills, abilities, and other characteristics (KSAOs) to be able to cope with various problems and be prepared for future professional life (Kay \& Morcarz, 2004). That is a critical requirement for them to gain a sustainable competitive advantage (Lepak \& Snell, 1999; Auw, 2009; Ployhart \& Moliterno, 2011).

\subsection{The Competency Domain Model}

As the main purpose of the study was to discover core competencies for hotel executives, a popular model on the classification of competencies put forth by Sandwith (1993) was employed to be able to predicate the work on a further theoretical frame as fleshed out under the findings section.

The competency domain model (CDM) was based on Katz's (1955) concept of skills needed by supervisors, managers, and executives in organizations. Katz (1955) identified three fundamental areas that consisted of technical, human, and conceptual skills for managers at different levels. However, the CDM delineated competencies by extending these three areas through field research into five specific domains as follows; (1) conceptual/creative, (2) leadership, (3) interpersonal, (4) administrative, and (5) technical. The five-domain model propounds that the core activity of managers is to make decisions. The decision-making process consists of choosing appropriate responses based on perceived factors in a particular activity, and it pivots on the competencies possessed by the decision-maker outlined in the specified domains.

In summary, the conceptual/creative domain refers both to the cognitive skills that are associated with comprehending important elements of a job and to the understanding of brain-mind functioning and creative thought. The leadership domain turns thought into productive action by providing a strategic link between the conceptual/creative domain and the other domains. The interpersonal domain concentrates on the skills for effective interaction with others, such as customers and organizational peers. The technical domain refers to the actual work that the organization does, while the administrative domain is thought to have evolved as a way of addressing those areas of activity in organizations that lie between the interpersonal and the technical domains. Namely, it refers to the personnel and financial management aspects of organizational life.

\subsection{Setting the Hypotheses}

Stated in the introduction, researchers such as Tas (1988) and Baum (1990) determined competencies 
for general managers (GMs) by consulting hotel professionals. Studies of Nelson \& Dopson (2001), Christou (2002), and Nolan et al. (2010) examined them in a broader context by comparing expectations of professionals with those of graduates. However, the study, being inspired by the latter, aims to compare the perceptions of professionals with those of academics as it was believed that instead of just relying on graduates, also asking for opinions of academics would be a more advantageous choice, since academics are one of the distinctly qualified stakeholders of the industry, and thus well capable of assessing the hospitality management competencies.

Following the second purpose of the study, the perceptions of professionals and academics of hospitality management competencies that were delineated in the four domains of the CDM were statistically compared, and thus the hypotheses tested are as follows;

Hypothesis 1:There is a significant difference between the perceptions of professionals and academics of the conceptual/creative domain,

Hypothesis 2: There is a significant difference between the perceptions of professionals and academics of the leadership domain,

Hypothesis 3: There is a significant difference between the perceptions of professionals and academics of the interpersonal domain,

Hypothesis 4: There is a significant difference between the perceptions of professionals and academics of the administrative domain.

\section{Methodology}

\subsection{The Population and Determining the Sample Size}

The study was carried out in Turkey, located in Southeast Europe. The population of the study consisted of both GMs and HR managers (HRMs) of five-star hotels and Ph.D. graduate academics employed as professors at the higher tourism programs of the country. The Ministry of Culture and Tourism reported that there was a total of 618 five-star hotels by the end of 2015 . The majority of those were regular five-star (523), and the rest consisted of resorts (67) and thermal hotels (28). As the population of professionals was based on the given numbers, only one manager (either a GM or HRM) per hotel was surveyed. On the other hand, the second group was comprised of 475 academics who were affiliated with higher tourism programs in tourism, business, business and management, commercial sciences, economics, economic and administrative sciences, economic-administrative and social sciences schools as reported by the Council of Higher Education (December 2016). Of the 475 academics, 322 were employed as assistant professors, 98 as associate professors, and 55 as professors. By depending on these statistics, the sample size was determined to be approximately 243 for the professionals, and 218 for the academics with a 95 percent confidence and $p=$ .5 using the equation proposed by Yamane (1967) and restated by Israel (1992).

\subsection{Data Collection, Survey Design, and Pilot Testing}

Based on survey research, the study employed a questionnaire that is used to gather information on the backgrounds, behaviors, beliefs, or attitudes of large numbers of people. The questionnaire layout consisted of two parts. Part one measured the participants' demographics, such as age, gender, education and occupation, job experience, job position, and job affiliation. The age variable was adapted from the United Nations' (2016) age classification for social stratification and mobility, while the job experience variable was derived from Pardo \& Ruiz-Tagle (2017).

Part two consisted of competency statements that measured the perceptions of participants. The statements were arranged in five-point Likert type scaling that was comprised of essential (mean rating over 4.50 ), very important (4.49-3.50), important (3.49-2.50), slightly important (2.49-1.50) and unimportant (under 1.49) categories (Tas, 1988; Nelson \& Dopson, 2001).

Part two was designed using two sources. The first source was the previous studies on hospitality management competencies, such as Tas (1988), Tsai, Goh, Huffman \&Wu (2006), Nolan et al. (2010), and Cheung, Law \& He (2010). As the main source of the study, all 36 competency items of Tas (1988) were adopted. Tas (1988) was conducted in the US; therefore, two of the items were slightly altered in the path of Baum (1990) and Christou (2002) as these two suited the nature of our study better. Each competency item of the four studies was compared one to another, and consequently, 29 items that differed from those of Tas (1988) were also adopted. Of the 29 items, 15 were derived from Nolan et al. (2010), 12 from Tsai et al. (2006), and 2 from Cheung et al. (2010).

The second source was job ads. Job ads seem to be a good source for driving implications on employers' 
expectations of employee quality. Therefore, the second examination was conducted on the top-browsed career websites of Turkey (Alexa, 2016), such as kariyer. net, eleman.net, yenibiris.com, secretcv.com, and elemanonline.com.tr. These websites were browsed periodically from March 1 through March 24, 2016, just before the domestic peak season of the industry, and about three hundred advertisements published on those websites were recorded down electronically. These ads were analyzed by employing a content analysis that is a good way of analyzing big data such as web sources easily, effectively, and systematically.

The job ads analysis resulted in a list of 179 items in total. 24 of the items were eliminated from the list as they did not possess any attribute of a competency approach. The remainders were sorted by importance depending on the categories derived from Nelson \& Dopson (2001) and Brown (2010). Consequently, a total of 14 items that fell under the categories of essential, very important, important, and slightly important were compared with the items retrieved from the literature review as described above. The comparison showed that most of the items corresponded in meaning. Therefore, some of the items were altered to extend and update their meanings, while some others were left as is. Consequently, final items decided to be included in the questionnaire, either as pristine or altered, are shown in Table 1.

Table 1: Final Items Added in the Questionnaire after Literature - Job Ads Comparison

\begin{tabular}{l}
\hline Competency statements \\
\hline Knows multiple languages both written and orally \\
Uses business technology effectively (e.g., reservation \\
systems, MS Office, electronic cash registers, POS devices, etc.) \\
Thinks customer satisfaction-oriented \\
Knows budgeting \\
Possesses needed leadership qualities [e.g., analytical/ \\
critical thinking skills (problem-solving, etc.), team working \\
skills, etc.] to achieve organizational objectives \\
Knows sales techniques
\end{tabular}

Following the analyses, the raw-form questionnaire of sixty-seven competency items underwent a couple of pilot tests. Although there is always some probability of error, and no measurement is perfectly reliable at all, pretesting is a good way of increasing the reliability of research.
The initial pretest was carried out in EMITT 2017, one of the prominent international tourism fairs of Europe with purposive sampling that is a method providing a chance to pick cases that are judged to be typical of the population. During the four-day fair, GMs or HRMs of the participating five-star hotels were asked to fill out the draft questionnaire, and consequently, 21 responses were returned in total. Just a few days later, the draft also was either emailed or handed in person to some of the prominent tourism academics of the country. 8 of the academics responded favorably soon after. Eventually, data obtained through a total of 29 questionnaires were tested for its reliability through SPSS, and the analysis resulted in high internal consistency of the 67 items, Cronbach's $a=.96$.

The initial pretest was conducted concurrently with cognitive interviewing through which participants frankly convey their thoughts, thinking aloud to assess the functionality and validity of the questionnaire. Some capable participants were asked for their opinions on the overall design. By eliciting much cordial regard, some of the participants commented that the questionnaire looked quite fine. For some other participants, it seemed to be a product of a detailed work mirroring the prevalent expectations of the professionals. These comments could be construed as if the questionnaire's face validity was achieved in general. However, some people also commented that it was too long in size, thus exhausting and dramatically time-taking. As to Neuman (2014), there is no definite length in questionnaires, but as their length increases, the chance of responding decreases substantially. Lund \& Gram (1998) also state that the length of a questionnaire affects the response rate significantly. Therefore, the length of the questionnaire was decided to be lessened to a more reasonable degree to make it more compact and applicable. According to Tas (1988), competencies over 3.50 should be regarded as considerably important. By relying on that, items below 3.50 were removed from the list to reduce the burden on participants, reduce the probability of error in response due to inattention to the response task, increase their possibility of participation, and thus boost the attendance rate.

The rectified questionnaire was emailed to more sampling units to test its new format, and consequently, the attendance rate doubled in quite a short time. Furthermore, as it is hard enough to expect consistent reactions from participants regarding a questionnaire, and as there is always some risk of bias, the questionnaire's design, color, and rubric that could discomfort 
the viewer were revised to minimize such potential negative effectors.

The revised form of the questionnaire was sent to sampling units online, which is one of the cheapest, simplest, and fastest methods. The delivery was made with simple random sampling that is a probability sampling technique in which every member of the population has an equal chance of being selected. Eventually, data obtained from a total of 114 questionnaires were tested for its reliability in which 48 competency statements had high internal consistency, Cronbach's $a=.96$.

As both pilot tests proved that the questionnaire was highly reliable, the final form of it was sent to the population online. However, the professionals were contacted by phone initially to ask for their participation in the survey and get their email addresses. Along with that, executives of some of the largest hotel chains and hotel associations were contacted to ask for their reference to augment participation. Thereafter, most of the professionals and the academics were invited via email to participate in the online survey. It took months to distribute the questionnaire to the population. Many of the sampling units that received online invitation responded in a few days, while it took much more for the others to respond. Many sampling units were prompted a couple of times to attend the survey. Finally, over a ten-month effort resulted in 462 responses in total.

\subsection{Statement of the Normality Assumption}

The study was based on parametric testing. Before conducting a parametric test, data sets to be analyzed are generally tested for their normality and are expected to have a normal distribution. However, according to the central limit theorem, if samples are larger than 30 (40 or 200 in some statements), the sampling distribution is supposed to be normally distributed in any case without applying to any certain criteria.

\section{Findings and Discussion}

\subsection{Demographics of the Participants}

Demographics analysis determined that most of the participants (53\%) were professionals, while the others were academics, as shown in Table 2. Of the whole participants, 48 percent were females, and 52 percent were males. Almost all the participants were middle-aged (71 percent were aged between 24 and 44). 28 percent were aged between 45 and 64.1 percent of the participants were aged over 65 , and less than one percent was aged under 24. Regarding their positions, 44 percent of the participants were HRMs. 26 percent were assistant professors. 15 percent were associate professors. 9 percent were $\mathrm{GMs}$, and 6 percent were full professors. Besides, more than one half of them (55\%) held a graduate degree (at least a master's degree), which indicated that most of the participants were highly intellectual. 35 percent held an undergraduate degree, and 8 percent held an associate degree, while only 2 percent graduated from either a middle or high school. Along with that, 42 percent of the participants majored in tourism. 28 percent majored in business administration. 7 percent majored in economics, and the rest majored in some other fields. Finally, 47 percent of the participants had a work experience of 0-12 years. 30 percent had a work experience of 13-21 years, and 23 percent had work experience of $22+$ years.

\subsection{Classifying the Core Competencies through a PCA Analysis}

In this section, factor analysis was employed to discover and understand the structure of the latent variables of the data set, reduce it to a more manageable size, explore how well the items are related to each other, form clusters or factors, and thus group them by more generic names. Therefore, a principal component analysis (PCA) that is of the same functionality with factor analysis and a special case of it, yet, a less complex technique was conducted on the 48 items with orthogonal rotation (varimax). As shown in Table 3 , the Kaiser-Meyer-Olkin measure verified the sampling adequacy for the analysis, $\mathrm{KMO}=.87$, and all $\mathrm{KMO}$ values for individual items were above the acceptable limit of .5 (Field, 2009). Bartlett's test of sphericity $X^{2}(105)=$ $2479.78, p<.000$, indicated that correlations between items were adequately large for PCA. An initial analysis run to obtain eigenvalues for each component in the data suggested that four components had eigenvalues over Kaiser's criterion of 1 and explained $63.5 \%$ of the variance overall.

The analyses were conducted with theoretical reference of the CDM outlined before, and thus competencies of which's categorization did not comply with the theory were omitted from the measure. Hence, of the fifteen items that clustered around four factors, factor 1 consisting of three items referred to the conceptual/creative domain. Factor 2, consisting of five items referred to the leadership domain. Factor 3 consisting of three items referred to the interpersonal domain, and factor 4 , consisting of four items referred to the 
administrative domain. However, no item corresponded to the technical domain, which was ascribed to the fact that the research was conducted considering the senior management positions. Following the categorization phase of the competency statements, a reliability analysis was conducted to test the internal consistency of the residuals. The results indicated that all domains had a moderate reliability; conceptual/ creative domain, Cronbach's $a=.74$, leadership domain, Cronbach's $a=.81$, interpersonal domain, Cronbach's $a$ $=.77$, and administrative domain, Cronbach's $a=.79$.

Table 2: Demographics of the Participants

\begin{tabular}{llll}
\hline & & Frequency & Percent \\
\hline Group & Professional/Academic & $244 / 218$ & $52.8 / 47.2$ \\
Gender & Female/Male & $220 / 242$ & $47.6 / 52.4$ \\
Age & (Under) 24/25-44/45-64/(Over) 65 & $6 / 326 / 128 / 2$ & $1.3 / 70.6 / 27.7 / .4$ \\
Position & GM/HRM/Asst.Prof./Assoc. Prof./Prof. & $40 / 204 / 121 / 68 / 29$ & $8.7 / 44.2 / 26.2 / 14.7 / 6.3$ \\
Education Degree & Middle or high school/Associate/Undergraduate/ & $11 / 36 / 163 / 252$ & $2.4 / 7.8 / 35.3 / 54.5$ \\
& Graduate & & \\
Major field & Tourism/Business administration/Economics/Other & $196 / 129 / 32 / 105$ & $42.4 / 27.9 / 6.9 / 22.7$ \\
Work Experience & $0-12 / 13-21 /(O v e r) 22$ & $217 / 140 / 105$ & $47.0 / 30.3 / 22.7$ \\
\hline
\end{tabular}

Table 3. Results of the PCA Analysis: Competencies Delineated into the Four Domains of the Competency Domain Model

\begin{tabular}{|c|c|c|c|c|}
\hline & \multicolumn{4}{|l|}{ Factors } \\
\hline & $\begin{array}{l}\text { Conceptual/ } \\
\text { Creative }\end{array}$ & Leadership & Interpersonal & Administrative \\
\hline $\begin{array}{l}\text { Uses past and current information to predict future } \\
\text { departmental revenues and expenses }\end{array}$ & .839 & & & \\
\hline $\begin{array}{l}\text { Uses past and current information to predict future } \\
\text { hotel reservations }\end{array}$ & .827 & & & \\
\hline $\begin{array}{l}\text { Assists in establishing organizational objectives and } \\
\text { their priorities }\end{array}$ & .525 & & & \\
\hline $\begin{array}{l}\text { Possesses needed leadership qualities [e.g., analy- } \\
\text { tical/critical thinking skills (problem-solving, etc.), } \\
\text { team working skills, etc.] to achieve organizational } \\
\text { objectives }\end{array}$ & & .750 & & \\
\hline $\begin{array}{l}\text { Strives to achieve positive working relationships } \\
\text { with employees }\end{array}$ & & .713 & & \\
\hline $\begin{array}{l}\text { Maintain professional and ethical standards in the } \\
\text { work environment }\end{array}$ & & 683 & & \\
\hline $\begin{array}{l}\text { Motivates employees to achieve the desired perfor- } \\
\text { mance }\end{array}$ & & 665 & & \\
\hline Demonstrates professional appearance and poise & & 633 & & \\
\hline $\begin{array}{l}\text { Manages guest problems with understanding and } \\
\text { sensitivity }\end{array}$ & & & .842 & \\
\hline Develops positive customer relations & & & .823 & \\
\hline Thinks customer satisfaction-oriented & & & .701 & \\
\hline $\begin{array}{l}\text { Follows hygiene and safety regulations to ensure } \\
\text { compliance by the organization }\end{array}$ & & & & .799 \\
\hline $\begin{array}{l}\text { Effectively manages life-threatening situations, such } \\
\text { as fire, bomb threat, serious illness, etc. }\end{array}$ & & & & .760 \\
\hline $\begin{array}{l}\text { Follows established personnel management proce- } \\
\text { dures in the supervision of employees }\end{array}$ & & & & .700 \\
\hline $\begin{array}{l}\text { Follows the legal responsibilities associated with } \\
\text { hotel operations }\end{array}$ & & & & .682 \\
\hline Eigenvalues & 1.94 & 2.87 & 2.13 & 2.58 \\
\hline$\%$ of variance & 12.91 & 19.14 & 14.22 & 17.23 \\
\hline Cronbach's a & .74 & .81 & .77 & .79 \\
\hline
\end{tabular}




\subsection{Testing of the Hypotheses}

The four hypotheses of the study stated above were tested by employing a series of independent samples t-tests to determine whether the two groups' means were different from each other. The results shown in Table 4 are reported in the following sections.

Perceptions of the participants of the conceptual/creative domain. Hypothesis 1: There is a significant difference between the perceptions of professionals and academics of the conceptual/creative domain

The results of the t-test carried out to test Hypothesis 1 indicated that there was no significant difference between the perceptions of professionals and academics of the conceptual/creative domain. Therefore, Hypothesis 1 was not supported, which means professionals and the academics concurred on the importance level of the conceptual/creative domain.

Perceptions of the participants of the leadership domain. Hypothesis 2: There is a significant difference between the perceptions of professionals and academics of the leadership domain

The results of the t-test carried out to test Hypothesis 2 indicated that there was no significant difference between the perceptions of professionals and academics of the leadership domain. Therefore, Hypothesis 2 was not supported, which means professionals and academics also concurred on the importance level of the leadership domain.

Perceptions of the participants of the interpersonal domain. Hypothesis 3: There is a significant difference between the perceptions of professionals and academics of the interpersonal domain

The results of the t-test carried out to test Hypothesis 3 indicated that there was a significant difference between the perceptions of professionals and academics of the interpersonal domain, $p<.05$. Therefore, Hypothesis 3 was supported, meaning professionals and academics do not concur on the importance level of the interpersonal domain. Furthermore, the group statistics chart revealed that academics' mean $(M=-, 14$, $S E=, 06)$ was larger than that of professionals $(M=, 13$, $S E=, 06)$.

Perceptions of the participants of the administrative domain. Hypothesis 4: There is a significant difference between the perceptions of professionals and academics of the administrative domain
The results of the t-test carried out to test Hypothesis 4 indicated that there was a significant difference between the perceptions of professionals and academics of the administrative domain, $p<.05$. Therefore, Hypothesis 4 was supported, meaning professionals and the academics do not concur on the importance level of the administrative domain just as it was in the interpersonal domain. It should be also noted that academics' mean $(M=-, 10, S E=, 07)$ was larger than that of professionals $(M=, 09, S E=, 06)$.

Testing the effect of demographics on the participants' perceptions. Apart from the t-test analyses, a couple of two-way ANOVA tests were carried out to see whether perceptions of the two groups were affected by some demographics, such as gender, age, work experience, and major (field of specialization). The results indicated that their perceptions were not affected by gender, age, or work experience. However, they were significantly affected by their majors (i.e., tourism, business administration, economics, and other), $p<.05$. The Bonferroni post hoc test revealed that there was a significant difference between the major of tourism and the major of business administration, $p<.05$. The test rendered no other significant-difference results for the rest of the pairs of comparison between the four categories of major.

\subsection{Comparing the Competency Means with the Antecedents}

As one of the purposes of the study was to appraise the results regarding the previous studies, this section was allotted to the comparison of competency means with those of some antecedents. Because of the unique pattern of the study, it was not possible to compare its results in every detail with its counterparts. However, there are a couple of renowned studies, such as Tas (1988), Baum (1990), Christou \& Eaton (2000), Christou (2002), and Whitelaw (2005), that allowed us to make some inferences from one-on-one item comparisons. The means of the competencies, as shown in Table 5 , revealed that there is an inconsistent pattern of the overall means except for the first item (C1). This fluctuating pattern seems to be quite natural when some factors are considered. These variations may be resulting from the fact that these studies were carried out in uncontrollably different settings and several countries. Besides, the data was gathered from the studies conducted at discrete time segments. For example, it has been almost thirty years between the first and last studies. Apart from those, there might be 
some perceptual biases due to linguistic dissimilarities and cultural diversities.

One thing to note is that all means of the six studies are over 3.50, indicating each competency statement falls either into the category of very important or into the category of essential. In that case, the means above, along with the overall findings, suggest that the competencies listed in Table 5 are critical in entering the senior management positions of the industry. For example, by mutual consent of the five studies except for Ireland, $\mathrm{C} 1$ is the most important competency, although the means vary by study. As five of the means are over 4.50, C1 falls into the category of essential. Likewise, the study consists with Baum (1990) on C5, C6, C13, and C15, with Whitelaw (2005) on C4 and C5, and finally with Christou (2002) on C7 and C15 that reinforces the validity of those items. Furthermore, $\mathrm{C} 2, \mathrm{C} 4, \mathrm{C} 8$, $\mathrm{C} 10, \mathrm{C} 13$, and $\mathrm{C} 14$ have exalted overall despite their lower means when compared to the previous studies. Contrariwise, $\mathrm{C} 6, \mathrm{C} 9$, and $\mathrm{C} 12$ have abased in general. $\mathrm{C} 5, \mathrm{C} 7, \mathrm{C} 11$, and $\mathrm{C} 15$ has a fluctuating pattern. C3 is a novel requisite for senior management candidates, which did not appear in the previous studies.

One thing to note is that the means of the study are lower than the means of other studies in general. For example, the highest value of the study is 4.51 , whereas it goes up to 4.89 in the others. Regardless of the counterparts, the study interestingly indicates that the competencies of interpersonal and leadership domains, chiefly but not barely, cluster in the upper rows of the list by the mean. With a more inconsistent pattern, the competencies of the administrative domain surpass those of the conceptual/creative domain. However, the leadership domain, with its five items outstands in general. Overall, the results seem rather decent and reasonable for a senior management position.

Table 4: The T-test Results of the Two Groups' Perceptions of the Competency Domains

\begin{tabular}{llllll}
\hline Domains & $\mathbf{t}$ & $\mathbf{d f}$ & Sig. (2-tailed) & Mean differences & Std. error differences \\
\hline Conceptual/Creative & .341 & 454 & .733 & .03197247 & .09383999 \\
Leadership & -1.846 & 454 & .066 & -.17261548 & .09350169 \\
Interpersonal & 2.981 & 454 & .003 & 27710716 & .09294653 \\
Administrative & 2.225 & 437.354 & .027 & .20868721 & .09378249 \\
\hline
\end{tabular}

Table 5: Means of the Competency Statements in Sequence and Comparison of the Studies

\begin{tabular}{|c|c|c|c|c|c|c|c|c|}
\hline & Core competencies & Domains & Means & $\begin{array}{l}\text { Whitelaw } \\
\text { (2005) } \\
\text { Ireland' }\end{array}$ & $\begin{array}{l}\text { Christou } \\
(2002) \\
\text { Greece }^{2}\end{array}$ & $\begin{array}{l}\text { Christou \& } \\
\text { Eaton (2000) } \\
\text { Greece }^{3}\end{array}$ & $\begin{array}{l}\text { Baum } \\
(1990) \\
\text { UK }^{4}\end{array}$ & $\begin{array}{l}\text { Tas } \\
(1988) \\
\text { USA }^{5}\end{array}$ \\
\hline $\mathrm{C} 1$ & $\begin{array}{l}\text { Manages guest problems with understanding and sen- } \\
\text { sitivity }\end{array}$ & Interpersonal & $1: 4.51$ & $10: 4.44$ & 1: 4.87 & 1:4.89 & $1: 4.81$ & 1: 4.80 \\
\hline $\mathrm{C} 2$ & $\begin{array}{l}\text { Follows the legal responsibilities associated with hotel } \\
\text { operations }\end{array}$ & Administrative & 2: 4.45 & 9: 4.45 & $10: 4.54$ & $11: 4.50$ & $7: 4.54$ & $14: 3.90$ \\
\hline C3 & Thinks customer satisfaction-oriented & Interpersonal & 3: 4.45 & - & - & - & - & - \\
\hline C4 & $\begin{array}{l}\text { Possesses needed leadership qualities [e.g., analytical/cri- } \\
\text { tical thinking skills (problem-solving, etc.), team working } \\
\text { skills, etc.] to achieve organizational objectives }\end{array}$ & Leadership & 4: 4.36 & 4: 4.50 & 8: 4.59 & $5: 4.60$ & 9: 4.40 & $7: 4.48$ \\
\hline $\mathrm{C} 5$ & Demonstrates professional appearance and poise & Leadership & 5: 4.33 & 5: 4.50 & $3: 4.73$ & 2: 4.83 & 5: 4.56 & 3: 4.61 \\
\hline C6 & Develops positive customer relations & Interpersonal & $6: 4.32$ & 2: 4.55 & $2: 4.76$ & $3: 4.72$ & $6: 4.55$ & 5: 4.60 \\
\hline $\mathrm{C7}$ & $\begin{array}{l}\text { Maintain professional and ethical standards in the work } \\
\text { environment }\end{array}$ & Leadership & 7: 4.30 & $12: 4.37$ & 7: 4.60 & $6: 4.58$ & 9: 4.40 & $2: 4.69$ \\
\hline $\mathrm{C} 8$ & $\begin{array}{l}\text { Assists in establishing organizational objectives and their } \\
\text { priorities }\end{array}$ & $\begin{array}{l}\text { Conceptual/ } \\
\text { Creative }\end{array}$ & $8: 4.21$ & - & $16: 4.31$ & $12: 4.42$ & $22: 3.92$ & $21: 3.67$ \\
\hline C9 & $\begin{array}{l}\text { Strives to achieve positive working relationships with } \\
\text { employees }\end{array}$ & Leadership & $8: 4.21$ & 6: 4.49 & 5: 4.66 & 4: 4.63 & 4: 4.57 & $6: 4.52$ \\
\hline C10 & $\begin{array}{l}\text { Effectively manages life-threatening situations, such as } \\
\text { fire, bomb threat, serious illness, etc. }\end{array}$ & Administrative & 9:4.20 & - & 13: 4.42 & $15: 4.33$ & 11: 4.37 & $11: 4.09$ \\
\hline C11 & $\begin{array}{l}\text { Follows hygiene and safety regulations to ensure compli- } \\
\text { ance by the organization }\end{array}$ & Administrative & $10: 4.15$ & 8: 4.49 & $11: 4.50$ & $13: 4.38$ & 2: 4.71 & 13: 3.99 \\
\hline C12 & Motivates employees to achieve desired performance & Leadership & $11: 4.14$ & $1: 4.60$ & $9: 4.57$ & 7: 4.58 & $8: 4.52$ & $8: 4.44$ \\
\hline C13 & $\begin{array}{l}\text { Uses past and current information to predict future } \\
\text { departmental revenues and expenses }\end{array}$ & $\begin{array}{l}\text { Conceptual/ } \\
\text { Creative }\end{array}$ & $12: 4.01$ & - & 19: 4.21 & $17: 4.24$ & $12: 4.31$ & $18: 3.75$ \\
\hline C14 & $\begin{array}{l}\text { Uses past and current information to predict future hotel } \\
\text { reservations }\end{array}$ & $\begin{array}{l}\text { Conceptual/ } \\
\text { Creative }\end{array}$ & 13: 3.94 & - & $20: 4.18$ & 22: 3.95 & 18: 4.06 & 23: 3.61 \\
\hline C15 & $\begin{array}{l}\text { Follows established personnel management procedures } \\
\text { in supervision of employees }\end{array}$ & Administrative & $14: 3.91$ & $32: 4.04$ & $14: 4.38$ & 19: 4.11 & $14: 4.23$ & $9: 4.33$ \\
\hline
\end{tabular}

Sources: 1Baum (2006), 2Christou (2002), 3Christou \& Eaton (2000), 4Baum (1990), 5Tas (1988). 


\section{CONCLUSION}

Even though the tourism industry has not been qualification-minded historically (Evans, 1993), the increasing internationalization, digitalization, and demands of the global market have required hotel employees, particularly the managers, to be equipped with the critical competencies to be able to achieve organizational service quality and success. This study identified the most recent competencies for being promoted and assigned to an executive position in the hotel industry. Despite being not truly coincident and conducted in different settings, circumstances, and time series, findings of the study confirm Tas (1988), Baum (1990), Christou \& Eaton (2000), Christou (2002) and Whitelaw (2005) in general, which indicates that the agreed competencies of the six studies are critically essential. Moreover, the study reveals that the critical competencies sought in entering the senior management positions refer to the leadership, interpersonal, administrative, and conceptual/creative domains. Therefore, candidates who are preparing themselves for senior management positions are expected to be competent in the specified domains. They should develop and improve their leadership, interpersonal, administrative, and conceptual/creative competencies to be successful in the business. They should be well equipped with up-to-date competencies in terms of the changing expectations of the industry.

The study also indicates that the professionals and the academics concur on the importance level of the conceptual/creative and leadership domains. However, they do not agree on the interpersonal and administrative domains. The gap between the perceptions of the two groups in Turkey of the core competencies might negatively affect the effective preparation of future hotel managers for the business. To eliminate such negativity, the two stakeholders should reciprocally cultivate a robust dialogue and collaboration. For example, they should cooperate closely in the training process of hospitality students. Apart from that, academics should closely follow the trends in the industry and update their curricula to help students improve their qualities, and thus meet the latest expectations of the professionals.

Furthermore, the study revealed that some demographic variables, such as gender, age, or work experience, do not affect the identification of critical competencies. In other words, professionals and academics decide the importance levels of competencies regardless of their genders, ages, and work experiences.
However, they determine the importance levels by depending on their majors.

The overall results drive us to make some recommendations for the development of human resources in the tourism and hospitality business. First, the employers should abstain from not being qualification-minded and breeding down-skilling cycle (see Baum, 2002). They should constantly try to cultivate competent people through human resource development instead. Organizations should set functional systems for opening and developing internal career paths of their staff to cope with high levels of staff mobility, knowledge, and skills transfer/migration. Besides, higher tourism institutions should provide the most proper settings for prospective hospitality managers to prepare them well for the challenging tourism business. Hospitality management candidates should seek to develop their competencies through formal, non-formal, and informal education and through on-the-job and off-the-job training to be able to meet the ultimate expectations of supervisors and customers. Finally, the stakeholders, such as professionals, scholars, and governors, should strive to build effective collaborative strategies to nurture competent human resources.

\section{Limitations of the Study and Further Research}

This study examined the core competencies for senior management positions in the hotel industry of Turkey. Aside from that, it compared the perceptions of the two principal stakeholders of those competencies and then compared the competencies' mean results with those of some antecedents.

Future studies perhaps would go over these studies' findings and test their validity in different contexts, locations, and time-series with different methods and populations. For example, a more extensive comparative study at the international level could investigate the latest expectations and requirements with regard to the competencies of human resources by involving successful professionals, specialists, academics, and also customers, using in-depth qualitative or quantitative methods. Further, future studies could attempt to develop advanced higher education curricula and methods/models for teaching, training, and developing students and trainees in light of the findings of extant studies on the subject. 


\section{References}

Alexa. (2016, March 15). The top 500 sites on the web. Retrieved from http://www.alexa.com/topsites.

Auw, E. (2009). Human capital capabilities and competitive advantage. International Review of Business Research Papers, 5(5), 25-36.

Ayres, H. (2006). Education and opportunity as influences on career development: Findings from a preliminary study in eastern Australian tourism. Journal of Hospitality Leisure Sports and Tourism Education, 5(1), 16-28.

Baum, T. (1990). Competencies for hotel management: Industry expectations of education. International Journal of Contemporary Hospitality Management, 2(4), 13-18.

Baum, T. (2002). Skills and training for the hospitality sector: A review of issues. Journal of Vocational Education and Training, 54(3), 343-364.

Baum, T. \& Kokkranikal, J. (2005). Human resource management in tourism. In L. Pender \& R. Sharpley (Eds.), The Management of Tourism. Chennai: Sage.

Baum, T. (2006). Human resource management for tourism hospitality and leisure: An international perspective. London: Thomson.

Baum, T. (2015). Human resources in tourism: Still waiting for change - A 2015 reprise. Tourism Management, 50, 204-212.

Belias D., Vasiliadis L. \& Velissariou E. (2020). Internal marketing int:The case of human resource empowerment on Greek hotels. In V. Katsoni \& T. Spyriadis (Eds.) Cultural and tourism innovation in the digital era. Cham: Springer.

Bouranta, N., Chitiris, L. \& Paravantis, J. (2008). The relationship between internal and external service quality. International Journal of Contemporary Hospitality Management, 21(3), 275-293.

Buergermeister, J. (1983). Assessment of the educational skills and competencies needed by beginning hospitality managers. Journal of Hospitality and Tourism Research, 8(1), 38-53.

Cheung, C., Law, R. \& He, K. (2010). Essential hotel managerial competencies for graduate students. Journal of Hospitality and Tourism Education, 22(4), 25-32.

Christou, E. \& Eaton, J. (2000). Management competencies for graduate trainees. Annals of Tourism Research, 27(4), 1058-1061.

Christou, E. (2002). Revisiting competencies for hospitality management: Contemporary views of the stakeholders. Journal of Hospitality and Tourism Education, 14(1), 25-32.

Crosby, P. B. (1980). Quality is free: The art of making quality certain. New York: Mentor.

D'Annunzio-Green, N., Maxwell, G. A. \& Watson, S. (2005). Human resource management issues in hospitality and tourism: Identifying the priorities. In N. D'Annunzio-Green, G. A. Maxwell \& S. Watson (Eds.), Human resource management: International perspectives in hospitality and tourism. Padstow: Thomson.

Devanna, M. A., Fombrun, C. \& Tichy, N. (1981). Human resource management: A strategic perspective. Organizational Dynamics, 9(3), 51-67.

Dieke, P. U. C. (2001). Human resources in tourism development: African perspective. In D. Harrison (Ed.), Tourism and the less developed world: Issues and case studies. Trowbridge: Cabi.

Dogru, T., Isik, C. \& Sirakaya-Turk, E. (2019). The balance of trade and exchange rates: Theory and contemporary evidence from tourism. Tourism Management, $74,12-23$.

Evans, J. (1993). Tourism graduates: A case of over-production. Tourism Management, 14(4), 243-246.

Evans, J. R. \& Dean, J. W. (2003). Total quality: Management organization and strategy. United States: Thomson-South Western.

Field, A. (2009). Discovering statistics using SPSS. Estella: Sage.

Fournier, H. \& Ineson, E. M. (2010). Closing the gap between education and industry: Skills' and competencies' requirements for food service internships in Switzerland. Journal of Hospitality and Tourism Education, 22(4), 33-42.

George, S. \& Weimerskirch, A. (1994). Total quality management strategies and techniques proven at today's most successful companies. United States: John Wiley \& Sons.

Gronroos, C. (1988). Service quality: The six criteria of good perceived service. Review of Business, 9(3), 10-13.

Hall, C. M. (2005). The role of government in the management of tourism: The public sector and tourism policies. In L. Pender \& R. Sharpley (Eds.), The management of tourism, Chennai: Sage.

Helm, S. (2003). Calculating the value of customer referrals. Managing Service Quality, 13(2), 124-133. 
Isik, C., Sirakaya-Turk, E. \& Ongan, S. (2019). Testing the efficacy of the economic policy uncertainty index on tourism demand in USMCA: Theory and evidence. Tourism Economics, 1-14, https://doi. org/10.1177/1354816619888346.

Isik, C., Dogru, T. \& Sirakaya-Turk, E. S. (2018). A nexus of linear and non-linear relationships between tourism demand renewable energy consumption and economic growth: Theory and evidence. International Journal of Tourism Research, 20(1), 38-49.

Israel, G. D. (1992). Determining sample size. Retrieved from https://a7852d97-a$62 \mathrm{cb3a1a-s-sites.googlegroups.com/site/}$ estadisticayunpocomas/tama\%C3\%B1 omuestra. pdf?atta-chauth=ANoY7crE4AnZRqdzHczqfNWB95NMtWdObXK77UBvLhbQKrDMyGaED_Ef-0SKYu8c78EEMdtfhhoYfQHihbq7OzqogTXQpGlvcR2kxFv813AbTHp2m7Gd3al0KbAJz0sBxqLt7M8AGnNKBHPfSOFJapYoO4gJ8WGAfd60OTDcTOgDCeS8jxRqmKf8Lv8bHIwFZUa1uwPgW5Sk_N7lu9gcm6_z_ hE-D93cYzaCZTynCobyW1QkCF_BIC4\%3D\&attredirects $=0$.

Jolliffe, L. \& Farnsworth, R. (2003). Seasonality in tourism employment: Human resource challenges. International Journal of Contemporary Hospitality Management, 15(6), 312-316.

Kandampully, J. \& Suhartanto, D. (2000). Customer loyalty in the hotel industry: The role of customer satisfaction and image. International Journal of Contemporary Hospitality Management, 12(6), 346-351.

Katz, R. L. (1955). Skills of an effective administrator. United States: Harvard Business School Publishing.

Kay, C. \& Moncarz, E. (2004). Knowledge skills and abilities for lodging management success. Cornell Hotel and Restaurant Administration Quarterly, 45(3), 285-298.

Kotler, P., Bowen, J. T. \& Makens, J. C. (2010). Marketing for hospitality and tourism, New Jersey: Pearson.

Lepak, D. P. \& Snell, S. A. (1999). The human resource architecture: Toward a theory of human capital allocation and development. The Academy of Management Review, 24(1), 31-48.

Lund, E. \& Gram, I. T. (1998). Response rate according to title and length of questionnaire. Scandinavian Journal of Public Health, 26(2), 154-160.

Mariampolski, A., Spears, M. C. \& Vaden, A. G. (1980). What the restaurant manager needs to know: The consensus. The Cornell Hotel and Restaurant Administrative Quarterly, 27(3), 77-81.
Morris, C. O. (1973). Job competencies expected of hotel and restaurant administration graduates with implications for curriculum development (Unpublished master's thesis). Oklahoma State University Faculty of Graduate College, Oklahama.

Nelson, A. A. \& Dopson, L. (2001). Future of hotel education: Required skills and knowledge for graduates of US hospitality programs beyond the year 2000 part one. Journal of Hospitality and Tourism Education, 13(5), 58-67.

Neuman, W. L. (2014). Social research methods: Qualitative and quantitative approaches. United States: Pearson Education.

Nolan, C., Conway, E., Farrell, T. \& Monks, K. (2010). Competency needs in Irish hotels: Employer and graduate perspectives. Journal of European Industrial Training, 34(5), 432-454.

Normann, R. (1977). Management for growth. Chichester:Wiley.

Oakland, J. S. (2014). Total quality management and operational excellence. Abingdon: Routledge.

Pardo, C. \& Ruiz-Tagle, J. (2017). The dynamic role of specific experience in the selection of self-employment versus wage-employment. Oxford Economic Papers, 69(1), 189-212.

Pfeffer, J. (1994). Competitive advantage through people unleashing the power of the work force. United States: Harvard Business School Press.

Ployhart, R. E \& Moliterno, T. P. (2011). Emergence of the human capital resource: A multilevel model. Academy of Management Review, 36(1), 127-150.

Rosander, A. C. (1985). Applications of quality controls in the service industries. United States: ASQC Quality Press.

Ross, J. E. \& Perry, S. (1999). Total quality management: Text cases and readings. United States: St. Lucie Press.

Sandwith, P. (1993). A hierarchy of management training requirements: The competency domain model. Public Personnel Management, 22(1), 43-62.

Swarbrooke, J. \& Horner, S. (2007). Consumer behaviour in tourism. Great Britain: Butterworth-Heinemann.

Tas, R. F. (1988). Teaching future managers. Cornell Hotel and Restaurant Administration Quarterly, 29(2), 4143.

Thite, M. (2019). e-HRM: Digital approaches directions \& applications. Abingdon: Routledge. 
Touminen, P. \& Kettunen, U. (2003). To fade or not to fade: That is the question in customer relationships too. Managing Service Quality, 13(2), 112-123.

Tsai, F. C., Goh, B. K., Huffman, L. \& Wu, C. K. (2006). Competency assessment for entry-level lodging management trainees in Taiwan. The Chinese Economy, 39(6), 49-69.

United Nations. (2016). Provisional guidelines on standard international age classifications. Retrieved from http://unstats.un.org/unsd/publication/SeriesM/ SeriesM_74e.pdf.

Williams, C. \& Buswell, J. (2003). Service quality in leisure and tourism. Trowbridge: Cabi.
Whitelaw, B. (2005). Hospitality management education in Ireland: Meeting industry needs a competency-based approach. Proceedings of Tourism and Hospitality Research in Ireland: Exploring the Issues. Portrush, University of Ulster.

Yamane, T. (1967). Elementary sampling theory. United States: Prentice-Hall.

Zaccaro, S. J. \& Klimoski, R. J. (2001). The nature of organizational leadership: an introduction. In S.J.Zaccaro \& R. J. Klimoski (Eds.), The nature of organizational leadership: Understanding the performance imperatives confronting today's leaders. United States: Jossey-Bass. 